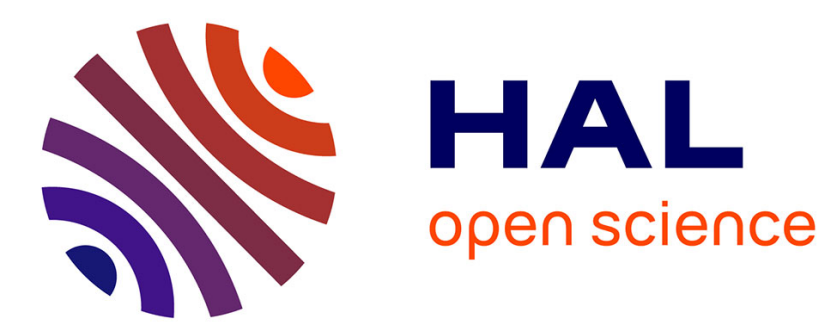

\title{
Plankton origin of particulate dimethylsulfoniopropionate in a Mediterranean oligotrophic coastal and shallow ecosystem
}

Natacha Jean, Gérard Bogé, Jean-Louis Jamet, Dominique Jamet, Simone Richard

\section{To cite this version:}

Natacha Jean, Gérard Bogé, Jean-Louis Jamet, Dominique Jamet, Simone Richard. Plankton origin of particulate dimethylsulfoniopropionate in a Mediterranean oligotrophic coastal and shallow ecosystem. Estuarine, Coastal and Shelf Science, 2009, 81 (4), pp.470 - 480. 10.1016/j.ecss.2008.12.006 . hal01884561

\section{HAL Id: hal-01884561 https://hal.science/hal-01884561}

Submitted on 1 Jun 2021

HAL is a multi-disciplinary open access archive for the deposit and dissemination of scientific research documents, whether they are published or not. The documents may come from teaching and research institutions in France or abroad, or from public or private research centers.
L'archive ouverte pluridisciplinaire HAL, est destinée au dépôt et à la diffusion de documents scientifiques de niveau recherche, publiés ou non, émanant des établissements d'enseignement et de recherche français ou étrangers, des laboratoires publics ou privés. 


\title{
Plankton origin of particulate dimethylsulfoniopropionate in a Mediterranean oligotrophic coastal and shallow ecosystem
}

\author{
Natacha Jean*, Gérard Bogé, Jean-Louis Jamet, Dominique Jamet, Simone Richard

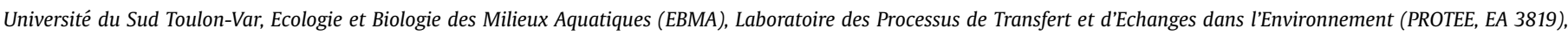
BP 20132, 83957 La Garde Cedex, France

Keywords:

DMSP

DMS

Mediterranean Sea

oligotrophic ecosystem

dinoflagellates

\begin{abstract}
A B S T R A C T
We report here dimethylsulfide (DMS) and dimethylsulfoniopropionate (DMSP) levels as a function of plankton communities and abiotic factors over a 12-month cycle in the Mediterranean oligotrophic coastal and shallow ecosystem of Niel Bay (N.W. Mediterranean Sea, France). Total particulate DMSP $\left(\mathrm{DMSP}_{p}\right.$ ) and DMS concentrations were highly seasonal, peaking during a spring (April) bloom at $8.9 \mathrm{nM}$ and $73.9 \mathrm{nM}$, respectively. Significant positive correlations were found between total $\operatorname{DMSP}_{p}$ concentration and the abundance or biomass of the dinoflagellate Prorocentrum compressum (Spearman's rank correlation test: $r=0.704 ; p=0.011$ ). Similarly, DMS concentrations peaked during the development of blooms of $P$. compressum and Gymnodinium sp. There seemed to be a positive relationship between the chlorophyll $a$ to pheopigment ratio and DMS concentrations, suggesting that DMS was released during phytoplankton growth. High DMS levels recorded in the shallow Niel Bay may also result from the activity of benthic macroalgae, and/or macrophytes such as Posidonia spp., or the resuspension of sulfur species accumulating in sediments. The fractionation of particulate DMSP into three size classes ( $>90 \mu \mathrm{m}, 5-90 \mu \mathrm{m}$ and $0.2-5 \mu \mathrm{m}$ ) revealed that 5-90 $\mu \mathrm{m}$ DMSP-containing particles made the greatest contribution to the total $\mathrm{DMSP}_{p}$ pool (annual mean contribution $=62 \%$ ), with a maximal contribution in April (96\%). This size class consisted mainly of dinoflagellates (annual mean contribution $=68 \%$ ), with $P$. compressum and Gymnodinium sp. the predominant species, together accounting for up to $44 \%$ of the phytoplankton present. The positive correlation between DMSP concentration in the 5-90 $\mu \mathrm{m}$ size class and the abundance of $P$. compressum (Spearman's rank correlation test: $r=0.648 ; p=0.023$ ) suggests that this phytoplankton species would be the major DMSP producer in Niel Bay. The DMSP collected in the $>90 \mu \mathrm{m}$ fraction was principally associated with zooplankton organisms, dominated by copepods (nauplii and copepodites). DMSP $>90$, not due to a specific zooplankton production, resulted from the phytoplankton cells ingested during grazing. The concomitant peaks of DMS concentration and zooplankton abundance suggest that zooplankton may play a role in releasing DMSP and/or DMS through sloppy feeding.
\end{abstract}

\section{Introduction}

Dimethylsulfide (DMS) is found principally in ocean surface waters, in which it is the most abundant volatile sulfur compound. Lovelock et al. (1972) were the first to postulate that DMS was responsible for the transfer of sulfur from the seas, through the air, to land surfaces, a role originally assigned to $\mathrm{H}_{2} \mathrm{~S}$. DMS is now widely thought to be the predominant natural source of atmospheric sulfur. Once emitted into the atmosphere, DMS is rapidly oxidized to generate methane sulfonic acid (MSA), $\mathrm{SO}_{2}$ and $\mathrm{SO}_{4}^{2-}$.

\footnotetext{
* Corresponding author.

E-mail address: jean@univ-tln.fr (N. Jean).
}

The oxidation products of DMS can then be converted into sulfate aerosol particles. These particles may serve as condensation nuclei (CN) for water vapor to form cloud condensation nuclei (CCN) reflecting back the incoming solar radiation. Through their CLAW hypothesis, Charlson et al. (1987) have suggested that DMS may affect climate by regulating the greenhouse effect. Indeed, global warming, by inducing higher levels of primary production, would be expected to lead to an increase in DMS production. Gondwe et al. (2003) recently estimated the contribution of DMS to climaterelevant non-sea-salt sulfate (nss $\mathrm{SO}_{4}^{2-}$ ) at $43 \%$ in the relatively pristine Southern Hemisphere, confirming the potential role of oceanic DMS in climate regulation.

DMS is generated by the enzymatic cleavage of ß-dimethylsulfoniopropionate (DMSP) by a bacterial or algal DMSP-lyase 
(Challenger, 1951). DMSP is produced by marine algae as an osmolyte and cryoprotectant (Kiene and Service, 1991; Kirst et al., 1991). DMSP and its degradation products have also been shown to have antioxidant properties in marine phytoplankton (Steinke et al., 2002; Sunda et al., 2002; Van Rijssel and Buma, 2002). Bacteria may use DMSP as a source of reduced sulfur, after demethylation or demethiolation of this biogenic compound (Kiene et al., 1999; Kiene et al., 2000). Howard et al. (2006) showed that "switch genes" were used by marine bacterioplankton to regulate the enzymatic conversion of DMSP into climate-active DMS. These authors demonstrated, in Roseobacter and SAR11 taxa, a glycinecleaving T-family protein with DMSP methyltransferase activity involved in DMSP demethylation to generate methylmercaptopropionate. This discovery indicates that a substantial fraction of global marine primary production avoid DMS formation. A regulatory gene, $d d d D$, was identified by Todd et al. (2007) in the marine bacterium Marinomonas. In its cloned form, this gene conferred the ability to generate DMS from DMSP on Escherichia coli, demonstrating the potential of this gene to regulate intracellular DMS production.

DMSP is differentially produced by phytoplankton species, the greatest DMSP producers being the coccolithophores, the genus Phaeocystis and the dinoflagellates (Liss et al., 1993). In nearshore waters, Turner et al. (1988) reported higher intracellular DMSP concentrations in flagellates $(650 \mathrm{mM})$ than in the phytoplankton community as a whole (between 37 and $95 \mathrm{mM}$ ). Belviso et al. (2000) also recorded high DMSP concentrations, of 355-972 mM, in dinoflagellates. High DMS concentrations are generally associated with blooms and the growth of DMSP producers, such as Phaeocystis sp. (Leck et al., 1990; Kwint and Kramer, 1996). According to Stefels et al. (1995), these concentrations result from strong activities of the bacterial and/or algal DMSP-lyase, which converts DMSP into DMS. The production of dissolved DMSP and DMS is also associated with the senescence of phytoplankton blooms (Turner et al., 1988; Leck et al., 1990).

Significant correlations between DMS concentrations and zooplankton biomass have also been reported (Leck et al., 1990; Yang et al., 2000). Zooplankton grazing on algal cells may release DMS indirectly, by transferring DMSP to the dissolved compartment and making it available for conversion into DMS by bacteria (Belviso et al., 1990; Wolfe et al., 1994). Dacey and Wakeham (1986) found that a third of the DMSP originating from Gymnodinium nelsoni and Prorocentrum micans ingested by the copepods Labidocera aestiva and Centropages hamatus was released into the culture medium as DMS, confirming the role of zooplankton grazing in the DMS cycle. Viruses, by inducing the lysis of algal cells, also contribute to DMS release (Malin et al., 1998). Taking all these data into account, studies increasing our understanding of the biogeochemistry of DMS and DMSP by analyses of the temporal and/or spatial variations of their concentrations, appear to be particularly relevant. Over the last 30 years, a large database has been established, recording DMS and DMSP concentrations in all oceans worldwide (Kettle et al., 1999; Kettle and Andreae, 2000). However, as pointed out by Michaud et al. (2007), few studies have reported changes in DMS and DMSP concentrations during annual cycles in coastal areas. Besides, with the exception of Ledyard and Dacey (1996), few authors have provided data for DMS and DMSP levels in oligotrophic coastal waters.

Over the last 20 years, productivity in the Mediterranean Sea has increased considerably, due to the addition of large amounts of anthropogenic inputs (Duarte et al., 1999). This trend is particularly marked in coastal areas, which are the best sites for investigating the influence of increased trophic levels on DMS and DMSP production. In previous studies, we carried out such investigations in a coastal ecosystem: the eutrophicated Little Bay of Toulon (N.W.
Mediterranean Sea, France) (Jean et al., 2005, 2006). In this ecosystem, which has high plankton abundances and biomasses, we found elevated particulate DMSP levels during dinoflagellate blooms, and high intracellular DMSP in the toxic and nitrophilic Alexandrium minutum. In this study, we sought to confirm the influence of eutrophication, by determining the conditions in which sulfur species are produced at a study site with a much lower trophic level. Niel Bay meets these criteria: it is more open to the sea than Little Bay of Toulon and has lower plankton abundances and biomasses, typical of oligotrophic marine coastal environments (Jamet et al., 2001, 2005). We report here DMS and DMSP concentrations over a 12-month period at this Mediterranean oligotrophic coastal study site, providing insight into the conditions in which sulfur species are produced by plankton communities in such an ecosystem.

\section{Materials and methods}

\subsection{Study site}

The study was carried out on the French N.W. Mediterranean coast, in a shallow station of Niel Bay (depth $5 \mathrm{~m}$ ), located at the end of the Giens peninsula, $15 \mathrm{~km}$ east of the city of Toulon (Central point: $43^{\circ} 05^{\prime} \mathrm{N}$ and $6^{\circ} 00^{\prime} \mathrm{E}$ ) (Fig. 1). Niel Bay is situated just $3 \mathrm{~km}$ north of Porquerolles Island, an official French conservation area. The East - West Liguro - Provençal stream influences the hydrodynamics of this bay, allowing exchanges between pelagic and coastal ecosystems all year. In summer, Niel Bay has limited tourist and fishing activity. This site, unpolluted and widely open to the sea, allows the development of large Posidonia spp. meadows (Paillard et al., 1993). In previous studies, we demonstrated that Niel Bay was oligotrophic, showing low levels of chlorophyll $a$, low zooplankton abundances and high zooplankton diversity (Jamet et al., 2001, 2005).

\subsection{Field sampling}

Seawater from Niel Bay was sampled for 12 months, from October 1999 to September 2000. Samples were systematically taken between 9.30 and $11.00 \mathrm{am}$, as the small tidal effects in the Mediterranean Sea (annual mean amplitude $<60 \mathrm{~cm}$ ) had no influence on the study site. Samples were always taken from a depth of $2 \mathrm{~m}$, using a Niskin 10-L sampling bottle (General Oceanic). DMSP $p$ analysis was performed on an 8-L aliquot. Samples for DMS determination were collected specifically, by filling a 1-L polyethylene bottle, so as to prevent headspace and degassing in the sampling bottle. DMS analysis was carried out as soon as the sample arrived at the laboratory (a maximum of $2 \mathrm{~h}$ after the start of sampling). Finally, 20-L samples were taken to study the phytoplankton community and for chlorophyll $a$ and protein determinations. Zooplankton were collected by vertical towing, using a net with a $90 \mu \mathrm{m}$ mesh ( $0.5 \mathrm{~m}$ in diameter; $2.5 \mathrm{~m}$ in length) equipped with a flow meter.

\subsection{Abiotic factors}

Precipitation values in the Toulon area were obtained from Météo-France (the French meteorological service). Temperature and salinity were measured at the Niel Bay station, at a depth of 2 m, with a WTW LF 197 electronic multi-parametric sensor. For phosphate $\left(\mathrm{P}-\mathrm{PO}_{4}\right)$ and nitrate $\left(\mathrm{N}-\mathrm{NO}_{3}\right)$ determinations, seawater was first filtered through a polyamide membrane (Nytrel-TI, UGB) with $0.2 \mu \mathrm{m}$ pores. Phosphate concentrations were then determined by a colorimetric method based on ammonium molybdate, as described by Murphy and Riley (1962). Nitrate concentrations 


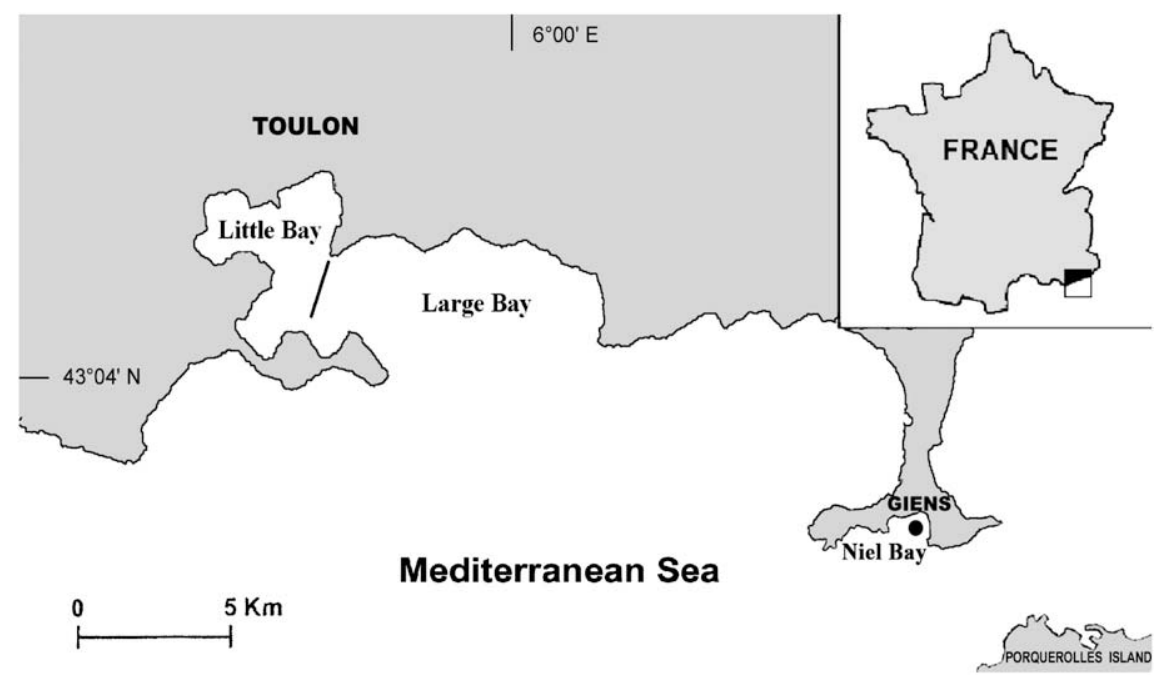

Fig. 1. Location of the sampling station in Niel Bay.

were determined with a Technicon II autoanalyzer (Diamond Diagnostics), using the cadmium reduction technique of Wood et al. (1967), as modified by Le Poupon (1994).

\subsection{Biotic factors}

\subsubsection{Pigments}

Particulate material was collected by filtering $20 \mathrm{~L}$ of seawater through glass fiber filters (Whatman GF/C). Pigments were then extracted from the particulate fraction in 90\% acetone. The extracted chlorophyll $a$ and pheopigments were analyzed by visible spectrophotometry (Uvikon Kontron Instruments), as described by Lorenzen (1967).

\subsubsection{Protein analysis}

The particulate material was fractionated into size classes by passing the $20 \mathrm{~L}$ of seawater successively through polyamide membranes with pore sizes of 90,5 and $0.2 \mu \mathrm{m}$ (Nytrel-TI, UGB). The proteins collected on the membranes were stored at $-80^{\circ} \mathrm{C}$ until analysis. The proteins of each class were resuspended in distilled water and analyzed with Folin phenol reagent (Lowry et al., 1951). Bovine serum albumin (BSA) was used as a standard.

\subsubsection{Phytoplankton}

A reverse filtration through a membrane with $0.2 \mu \mathrm{m}$ pores was first carried out to concentrate phytoplankton cells. The phytoplankton samples were then preserved and stored in Lugol's reagent until examination. Phytoplankton cells $>5 \mu \mathrm{m}$ in diameter were identified and counted under an inverted Nikon Diaphot microscope, with a technique first described by Utermöhl (1958) and subsequently modified by Legendre and Watt (1971-1972) (total magnification $\times 400$ ). As suspended material was present, we did not identify smaller cells (picoplankton). Cell biovolumes and biomasses were estimated in accordance with Lohman's (1908) calculation technique.

\subsubsection{Zooplankton}

Zooplankton samples collected with a net were stored in seawater-buffered $5 \%$ formol. Aliquots for counts were taken with a Hensen pipette from the total sample, the volume of which was adjusted to $250 \mathrm{~mL}$.

\subsubsection{Bacteria}

Bacteria were counted by epifluorescence microscopy, as described by Porter and Feig (1980). Water samples were filtered through a black polycarbonate Nucleopore filter (mesh size $0.2 \mu \mathrm{m}$; $25 \mathrm{~mm}$ diameter). After filtration, the membrane was covered with $1 \mathrm{~mL}$ of DAPI solution ( $50 \mu \mathrm{g} \mathrm{mL}^{-1}$ ) and left in the dark for staining. The stained filters were observed in a dark room, under an epifluorescence microscope (total magnification: $\times 1000$ ), with immersion oil.

\subsection{DMS and DMSP analysis}

$\operatorname{DMSP}_{p}$ was fractionated into size classes, by successively filtering seawater through filtration units with polyamide membranes (Nytrel-TI, UGB) having 90, 5 and $0.2 \mu \mathrm{m}$ pores. Gravity filtration was applied only with $90 \mu \mathrm{m}$-pore membranes. Low pressure $(<75 \mathrm{~mm} \mathrm{Hg}$ ) was used to separate the $5-90 \mu \mathrm{m}$ and the $0.2-5 \mu \mathrm{m}$ size classes. According to Kiene and Slezak (2006), the partitioning of DMSP between the particulate and dissolved compartments is affected by the filtration protocols commonly used, as cells may be lysed during the filtration procedure. As in a previous study by Jean et al. (2006), we estimated losses due to filtration by comparing the $\operatorname{DMSP}_{p}$ measurements obtained for samples filtered $(0.2 \mu \mathrm{m}$ pore size $)$ with and without pressure $(<75 \mathrm{~mm} \mathrm{Hg})$. We estimated DMSP $p$ losses at $37.3 \% \pm 7.9 \%(n=4)$.

Filters coated with particulate DMSP were stored at $-80^{\circ} \mathrm{C}$, in $15 \mathrm{~mL}$ hermetic polyethylene flasks, until analysis. Preliminary controls showed that freezing at $-80^{\circ} \mathrm{C}$ had no significant effect on DMSP content (Jean, 2002). Immediately before DMSP analysis, a filter with particulate DMSP of a given size class $(0.2-5,5-90$ or $>90 \mu \mathrm{m}$ ) was placed in $250 \mathrm{~mL}$ cold distilled water for resuspension of the particles. DMSP was extracted from the particulate fraction by sonication. It was then converted into DMS by the cold alkali treatment method (Dacey and Blough, 1987; Turner et al., 1988), by adding $\mathrm{NaOH}(10 \mathrm{M}$ ) to $\mathrm{pH} \sim 13$ (White, 1982; Stefels and Van Boekel, 1993). The alkaline solution was rapidly and kindly transferred to a silanized glass bottle with a septum and no headspace. The full transformation of DMSP into DMS was achieved after $24 \mathrm{~h}$ in the dark at $2{ }^{\circ} \mathrm{C}$. The DMS formed from DMSP was then analyzed as indicated below.

Seawater DMS concentrations were determined for a $250 \mathrm{~mL}$ sub sample of an unfiltered aliquot. DMS analysis was carried out with a modified version of a published method based on a cryo- 
trapping gas chromatographic technique (Simo et al., 1993; Simo, 1998). The gas chromatograph (DELSI 330) was equipped with a flame photometric detector (FPD) and a 1/8 inch PTFE column filled with Chromosil 330 (Supelco). A $5 \mathrm{~mL}$ sub sample was taken with a polyethylene needle. DMS was stripped by bubbling helium (99.9996\% quality) through the solution at a flow rate of $100 \mathrm{~mL} \mathrm{~min}{ }^{-1}$. The DMS was trapped on Tenax T.A. packed at $-40^{\circ} \mathrm{C}$, with magnesium perchlorate used as the dryer (Despiau et al., 2002). The Tenax was heated at $180^{\circ} \mathrm{C}$ and the released DMS was injected into the column. The flame photometric detector was supplied with a flow of air $\left(F_{\mathrm{a}}=150 \mathrm{~mL} \mathrm{~min}^{-1}\right)$ and hydrogen $\left(F_{\text {red }}=75 \mathrm{~mL} \mathrm{~min}^{-1} ; F_{\text {oxy }}=7 \mathrm{~mL} \mathrm{~min}^{-1}\right)$. DMS solution was used for calibration by linear interpolation: $\operatorname{Ln}$ (Peak area)-Ln(DMS mass). The detection limit was $2 \mathrm{ng}$ and the mean precision of DMS concentrations was $13 \%(n=9)$. The DMS and DMSP measurements were carried out in triplicate and mean values and standard deviations are presented.

\subsection{Statistical analysis}

In this work, the non-parametric Spearman's rank correlation test (Statistica 7.1 version) was used to compare chronological data series. This test indicates the existence of correlations between temporal variations of two variables. Correlations, characterized by $r$ and $p$ coefficients, were regarded as significant if $p<0.050$.

\section{Results}

\subsection{Abiotic factors}

More than $60 \%$ of the total annual precipitation occurred between October $(288.0 \mathrm{~mm})$ and November $(169.0 \mathrm{~mm})$ in the Toulon area, affecting Niel Bay water quality (Table 1). Salinity was particularly low from October (35.2) to December-January (36.2-36.3). Values typical of salinity in the Mediterranean (close to 38) were found again from February (38.1). Nutrient concentrations ranged from $2.0 \mu \mathrm{M}$ (September) to $19.7 \mu \mathrm{M}$ (December) (annual mean concentration $=5.8 \mu \mathrm{M}$ ) for nitrates, and from $53.5 \mathrm{nM}$ (August) to $168.0 \mathrm{nM}$ (November) (annual mean concentration $=98.3 \mathrm{nM}$ ) for phosphates (Table 1). These concentrations greatly increased in November $\left(\mathrm{PO}_{4}: 168.0 \mathrm{nM} ; \mathrm{NO}_{3}\right.$ : $13.1 \mu \mathrm{M})$ and December $\left(\mathrm{PO}_{4}: 149.0 \mathrm{nM} ; \mathrm{NO}_{3}: 19.7 \mu \mathrm{M}\right)$, coinciding with the heavy autumnal rains. Concentrations also rose in April for phosphate $(107.0 \mathrm{nM})$ and in May for nitrate $(9.2 \mu \mathrm{M})$, immediately after episodes of spring storms.

\subsection{Plankton communities}

\subsubsection{Biomass of the particulate fraction}

3.2.1.1. Chlorophyll a. Chlorophyll a concentration is regarded as a relevant indicator of phytoplankton biomass. Chlorophyll $a$ concentrations remained low throughout the year (annual mean value $=0.39 \mu \mathrm{g} \mathrm{L}^{-1}$ ), but displayed considerable fluctuations over time $\left(\min =0.10 \mu \mathrm{gL}^{-1} ; \max =1.00 \mu \mathrm{g} \mathrm{L}^{-1}\right.$ ) (Table 2). The largest

\section{Table 1}

Temporal variations in the abiotic factors in Toulon area (precipitation), and more specifically in Niel Bay (salinity, $\mathrm{N}-\mathrm{NO}_{3}, \mathrm{P}-\mathrm{PO}_{4}$ ).

\begin{tabular}{lrlrrrrrrrrrrr}
\hline Months & $\mathrm{O}$ & $\mathrm{N}$ & $\mathrm{D}$ & $\mathrm{J}$ & $\mathrm{F}$ & $\mathrm{M}$ & $\mathrm{A}$ & $\mathrm{M}$ & $\mathrm{J}$ & $\mathrm{J}$ & \multicolumn{1}{c}{$\mathrm{A}$} & \multicolumn{1}{c}{$\mathrm{S}$} \\
\hline $\begin{array}{l}\text { Precipitation } \\
\text { (mm) }\end{array}$ & 288.0 & 169.0 & 0.2 & 15.0 & 14.6 & 13.6 & 76.2 & 27.4 & 59.8 & 19.8 & 7.2 & 5.1 \\
$\quad$ & & & & & & & & & & & \\
Salinity & 35.2 & 35.6 & 36.3 & 36.2 & 38.1 & 37.9 & 37.8 & 37.8 & 38.0 & 38.0 & 38.2 & 38.3 \\
$\mathrm{~N}_{-} \mathrm{NO}_{3}(\mu \mathrm{M})$ & 5.9 & 13.1 & 19.7 & 5.5 & 2.9 & 2.1 & 2.2 & 9.2 & 2.6 & 2.2 & 2.1 & 2.0 \\
$\mathrm{P}_{-} \mathrm{PO}_{4}(\mathrm{nM})$ & 108.0 & 168.0 & 149.0 & 108.0 & 99.4 & 78.7 & 107.0 & 62.9 & 59.5 & 126.0 & 53.5 & 59.1 \\
\hline
\end{tabular}

variations were observed during autumnal rains, when chlorophyll a concentrations dropped from $1.00 \mu \mathrm{g} \mathrm{L}^{-1}$ (October) to only $0.19 \mu \mathrm{g} \mathrm{L}^{-1}$ (November). Three other relative peaks of chlorophyll a concentration occurred later, reaching 0.72 (February), $0.42 \mu \mathrm{g} \mathrm{L}^{-1}$ (April) and $0.51 \mu \mathrm{g} \mathrm{L}^{-1}$ (September). The lowest concentrations, around $0.10 \mu \mathrm{g} \mathrm{L}^{-1}$, were recorded in summer (June-July).

3.2.1.2. Proteins. We used protein analysis to determine the biomass of the total particulate fraction and the biomasses of the different particulate size classes. As described for chlorophyll $a$, total protein concentration decreased strongly in autumn, from $236.0 \mu \mathrm{g} \mathrm{L}^{-1}$ (November) to $71.0 \mu \mathrm{g} \mathrm{L}^{-1}$ (December) (Table 2). Biomass increased again in winter and spring, reaching more than $100 \mu \mathrm{g} \mathrm{L}^{-1}$ (May, January-March). Protein concentration then decreased again, stabilizing at about $100 \mu \mathrm{g} \mathrm{L}^{-1}$ in summer. The contributions of the three size classes $(>90 \mu \mathrm{m}, 5-90 \mu \mathrm{m}$ and $0.2-5 \mu \mathrm{m}$ ) to the pool of total particulate biomass were estimated (Table 2). Throughout the year, the 5-90 $\mu \mathrm{m}$ class was found to make the largest contribution to biomass, with an annual mean contribution of $61 \%$. The $>90 \mu \mathrm{m}$ fraction had the lowest protein concentrations, accounting for $5 \%$ (October, January and September) to $25 \%$ (April) of the total biomass (annual mean contribution $=28 \%$ ). By contrast, the $0.2-5 \mu \mathrm{m}$ size class collected much more biomass, ranging from $19 \%$ (June) to the highest value of $54 \%$ (April) (annual mean contribution $=11 \%$ ).

\subsubsection{Composition of the plankton communities}

3.2.2.1. Zooplankton. Zooplankton community consisted principally of copepods, which accounted for $78-97 \%$ of all zooplankton (Fig. 2). The cyclopoids predominated in the copepod community, with abundances corresponding to up to $87 \%$ of the entire copepod community. The copepod community was composed of adults, but especially of nauplii and copepodites, which were always the most abundant (up to 50 times more numerous than the adults). The abundance of adults peaked in February, at 412 individuals $\mathrm{m}^{-3}$, whereas the abundance of nauplii and copepodites peaked much later, in August, at around $2.8 \times 10^{4}$ individuals $\mathrm{m}^{-3}$.

3.2.2.2. Phytoplankton. The biomass of different phytoplankton species was estimated from phytoplankton abundances, as explained in Section 2.4.3. Phytoplankton biomass was clearly dominated by dinoflagellates, with an annual mean biomass of $68 \%$ the total for phytoplankton, against only $32 \%$ for diatoms (Fig. 3). Dinoflagellate biomass followed a clear seasonal pattern, with a peak at the end of spring ( $26.6 \mu \mathrm{g} \mathrm{L}^{-1}$ in May) resulting from the large biovolumes of Ceratium furca and of diverse species of the Protoperidinium genus. Lower values $\left(<5.0 \mu \mathrm{g} \mathrm{L}^{-1}\right)$ were observed during the rest of the year, except in September, when a moderate increase in dinoflagellate biomass $\left(8.3 \mu \mathrm{g} \mathrm{L}^{-1}\right)$ occurred. Diatom biomass followed a different pattern, with moderate increases in December $\left(8.6 \mu \mathrm{g} \mathrm{L}^{-1}\right)$ and May $\left(6.6 \mu \mathrm{g} \mathrm{L}^{-1}\right)$, coinciding with peaks in nitrate concentration. Two other relative peaks in diatom levels also occurred in February-March (about $5.0 \mu \mathrm{g} \mathrm{L}^{-1}$ ) and August (3.7 $\left.\mu \mathrm{g} \mathrm{L}^{-1}\right)$.

In the diverse phytoplankton community of Niel Bay, the most frequently represented dinoflagellates, in terms of abundance, were Prorocentrum compressum and Gymnodinium sp. (Fig. 4). Together, these two species accounted for $44 \%$ of the total phytoplankton community. Prorocentrum compressum was frequently the most abundant species present, at $29 \%$, versus $15 \%$ for Gymnodinium sp. The populations of these dinoflagellates

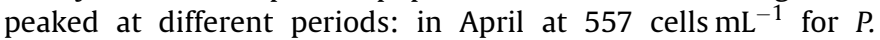
compressum, and later, in June, at 560 cells $\mathrm{mL}^{-1}$, for Gymnodinium sp. 
Table 2

Temporal variations in the biological factors in Niel Bay ( $\mathrm{PC}=$ contribution of a size class to the total protein biomass).

\begin{tabular}{|c|c|c|c|c|c|c|c|c|c|c|c|c|}
\hline Months & 0 & $\mathrm{~N}$ & $\mathrm{D}$ & $\mathrm{J}$ & $\mathrm{F}$ & M & A & M & $\mathrm{J}$ & $\mathrm{J}$ & A & $\mathrm{S}$ \\
\hline Chl- $a\left(\mu \mathrm{g} \mathrm{L}^{-1}\right)$ & 1.00 & 0.19 & 0.24 & 0.50 & 0.72 & 0.12 & 0.42 & 0.38 & 0.13 & 0.10 & 0.40 & 0.51 \\
\hline Total Protein $\left(\mu \mathrm{g} \mathrm{L}^{-1}\right)$ & 178.0 & 236.0 & 71.0 & 173.0 & 128.0 & 176.0 & 53.2 & 199.0 & 86.9 & 107.0 & 82.4 & 84.0 \\
\hline Protein $0.2-5\left(\mu \mathrm{g} \mathrm{L}^{-1}\right)$ & 45.4 & 75.7 & 19.0 & 51.5 & 27.9 & 50.1 & 28.7 & 39.3 & 16.5 & 26.6 & 21.0 & 19.9 \\
\hline$P C$ & $26 \%$ & $32 \%$ & $27 \%$ & $30 \%$ & $22 \%$ & $28 \%$ & $54 \%$ & $20 \%$ & $19 \%$ & $25 \%$ & $25 \%$ & $24 \%$ \\
\hline Protein 5-90 $\left(\mu \mathrm{g} \mathrm{L}^{-1}\right)$ & 124.0 & 130.0 & 43.6 & 114.0 & 72.7 & 115.0 & 11.0 & 144.0 & 62.9 & 61.6 & 55.9 & 59.9 \\
\hline$P C$ & $70 \%$ & $55 \%$ & $61 \%$ & $66 \%$ & $57 \%$ & $65 \%$ & $21 \%$ & $72 \%$ & $72 \%$ & $57 \%$ & $68 \%$ & $71 \%$ \\
\hline Protein $>90\left(\mu \mathrm{g} \mathrm{L}^{-1}\right)$ & 8.6 & 30.0 & 8.4 & 7.9 & 27.8 & 10.9 & 13.5 & 15.5 & 7.5 & 19.0 & 5.5 & 4.2 \\
\hline$P C$ & $5 \%$ & $13 \%$ & $12 \%$ & $5 \%$ & $22 \%$ & $6 \%$ & $25 \%$ & $8 \%$ & $9 \%$ & $18 \%$ & $7 \%$ & $5 \%$ \\
\hline
\end{tabular}

3.2.2.3. Bacteria. Bacterial abundance ranged from $9.2 \times 10^{4}$ cells $\mathrm{mL}^{-1}$ (February) to $2.9 \times 10^{5}$ cells $\mathrm{mL}^{-1}$ (April) (Fig. 5). Except for the peaks observed in autumn and in spring, bacterial abundance remained stable, at between 1.0 and $1.5 \times 10^{5}$ cells mL ${ }^{-1}$.

\subsection{DMS and DMSP concentrations}

\subsubsection{Total DMSP $P_{\mathrm{p}}$ concentrations}

Total DMSP $_{p}$ concentrations, obtained by summing DMSP concentrations for the $0.2-5,5-90$ and $>90 \mu \mathrm{m}$ size classes, varied between $0.5 \mathrm{nM}$ (November, July) and $8.9 \mathrm{nM}$ (April) (annual mean concentration $=2.6 \mathrm{nM}$ ) (Fig. 6). These concentrations followed a clear seasonal pattern: after low values in the autumn, total DMSP $_{p}$ peaked in March-April. We then observed a decrease in concentrations (between May and July) followed by a slight recovery (August-September). No correlation was found between total DMSP $p$ and chlorophyll $a$ or protein concentrations. Similarly, $\operatorname{DMSP}_{p}$ was not correlated with dinoflagellate abundance or biomass. However, significant positive correlations were found between total $\mathrm{DMSP}_{p}$ concentration and the abundance or biomass of the dinoflagellate species Prorocentrum compressum (Spearman's rank correlation test: $r=0.704 ; p=0.011$ ).

\subsection{2. $D M S$}

DMS concentrations were recorded throughout the year in Niel Bay (annual mean concentration $=19.8 \mathrm{nM}$ ) (Fig. 7). DMS concentrations peaked at $73.9 \mathrm{nM}$ in April, this peak coinciding with a peak in the total $\mathrm{DMSP}_{p}$ concentration (Fig. 6), development of the dinoflagellate Prorocentrum compressum (Fig. 4) and a peak in bacterial abundance (Fig. 5). These concentrations also increased to $11.8 \mathrm{nM}$ in February, during a moderate development of Gymnodinium sp. and a peak in zooplankton abundance (Figs. 2 and 4). Another DMS peak $(64.9 \mathrm{nM})$ occurred in August, when

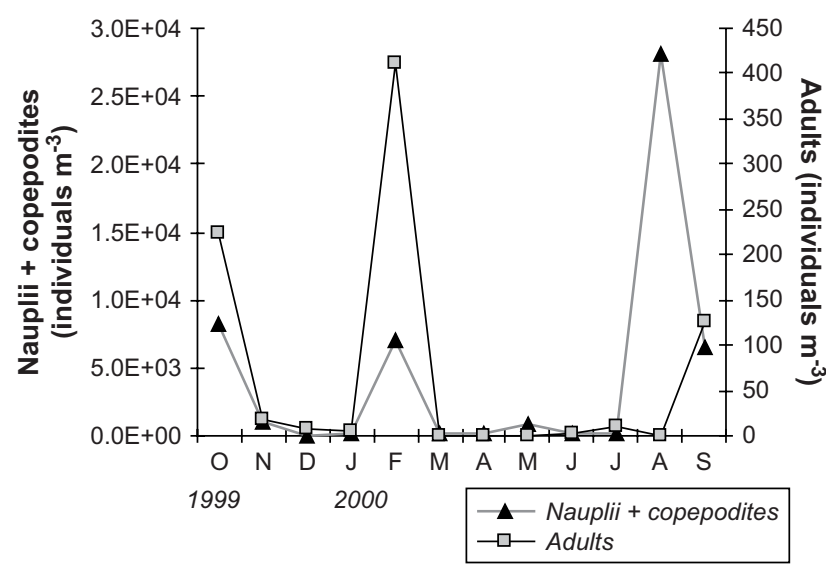

Fig. 2. Temporal variations in the abundance of the zooplankton community, consisting mostly of copepods (adults, nauplii + copepodites) in Niel Bay. zooplankton abundance (nauplii and copepodites) was maximal (Fig. 7).

The chlorophyll $a$ to pheopigment ratio provides information about the health of phytoplankton cells (Shenoy et al., 2006). Throughout the year, temporal variations in DMS concentrations seemed to be positively related to this ratio (Fig. 8). However, when this ratio peaked (24.0) in February, DMS concentrations also peaked, but to a lesser extent (11.8 $\mathrm{nM})$.

\subsubsection{Contribution of the $>90 \mu \mathrm{m}$ size class to total $D M S P_{\mathrm{p}}$ and to DMS}

DMSP levels in the $>90 \mu \mathrm{m}$ size class were low throughout the year, with concentrations not exceeding $0.7 \mathrm{nM}$ (Fig. 9). The highest DMSP levels in the $>90 \mu \mathrm{m}$ class occurred in February, June and August-September. This particulate fraction made a weak overall contribution to the total $\mathrm{DMSP}_{p}$ pool (annual mean contribution $=18 \%$ ).

In Niel Bay, $\mathrm{DMSP}_{>90}$ resulted from the zooplankton community, with most zooplankton organisms belonging to the $>90 \mu \mathrm{m}$ size class. $\mathrm{DMSP}_{>90}$ levels were highest at the time at which zooplankton abundance peaked (Fig. 2), in February for all copepods, coinciding with the chlorophyll $a$ peak corresponding to the development of diatoms and/or dinoflagellates (Fig. 3), and in August, for nauplii and copepodites only.

\subsubsection{Contribution of the 5-90 $\mu \mathrm{m}$ size class to total DMSP}

DMSP was much more abundant in the 5-90 $\mu \mathrm{m}$ size class than in larger particles, with concentrations ranging between 0.2 and $8.5 \mathrm{nM}$ (Fig. 9). DMSP ${ }_{5-90}$ concentrations increased strongly in March and April, at which times DMSP concentrations exceeded those in all the other fractions. As described for the total $\mathrm{DMSP}_{p}$, no correlation was found between DMSP $_{5-90}$ and chlorophyll $a$ or protein concentrations. Similarly, DMSP $_{5-90}$ was not correlated

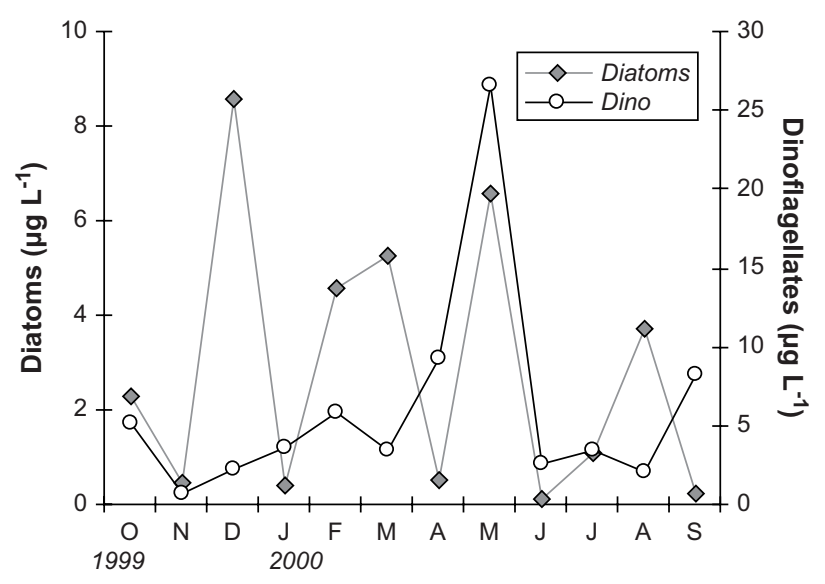

Fig. 3. Temporal variations in diatom and dinoflagellate biomasses in Niel Bay. 


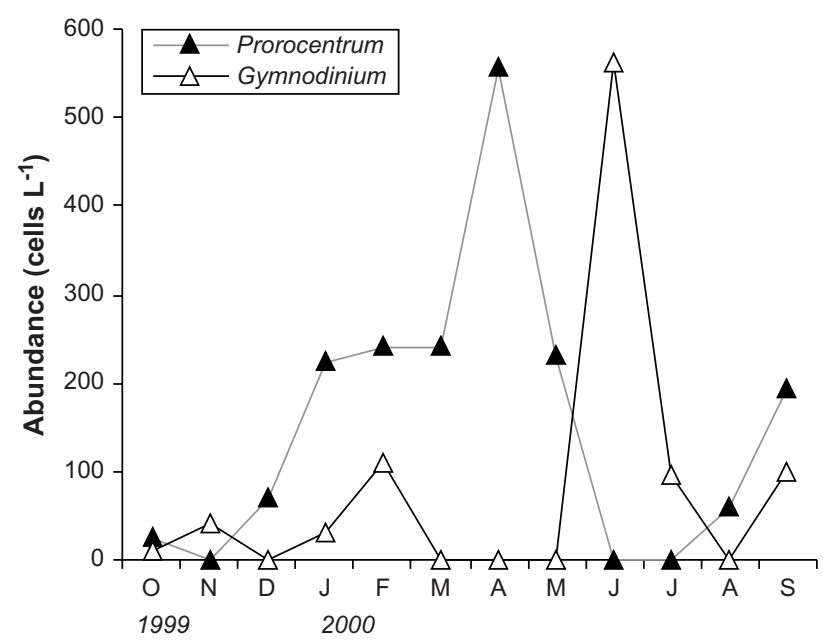

Fig. 4. Temporal variations in the abundance of the predominant dinoflagellate species, Prorocentrum compressum and Gymnodinium sp., in Niel Bay.

with dinoflagellate abundance or biomass. However, significant positive correlations existed between DMSP $_{5-90}$ and the abundance or biomass of the dinoflagellate species Prorocentrum compressum (Spearman's rank correlation test: $r=0.648 ; p=0.023$ ). The 5$90 \mu \mathrm{m}$ fraction made the greatest contribution to the total $\mathrm{DMSP}_{p}$ pool (annual mean contribution $=62 \%$ ). This contribution was particularly large in April (96\%), when total DMSP $p$ concentration reached its maximal value, suggesting that the main DMSP producers belonged to the $5-90 \mu \mathrm{m}$ size class.

\subsubsection{Contribution of the $0.2-5 \mu \mathrm{m}$ size class to total $D M S P_{\mathrm{p}}$}

DMSP was present in the same low proportions in this size class as in the $>90 \mu \mathrm{m}$ class. Like this fraction, the $0.2-5 \mu \mathrm{m}$ size class made a small contribution to the total $\mathrm{DMSP}_{p}$ pool (annual mean contribution $=20 \%$ ), with DMSP $_{0.2-5}$ concentrations remaining below $1.0 \mathrm{nM}$ (Fig. 9).

The highest DMSP levels in this size class were recorded in January (1.0 nM), March $(0.9 \mathrm{nM})$ and September $(0.7 \mathrm{nM})$. This fraction consisted of picoplankton, comprising bacteria and small phytoplankton cells, these phytoplankton cells not being counted in this study. However, no correlation was found between DMSP $_{0.2-5}$ and bacterial abundance, chlorophyll $a$ or protein concentrations.

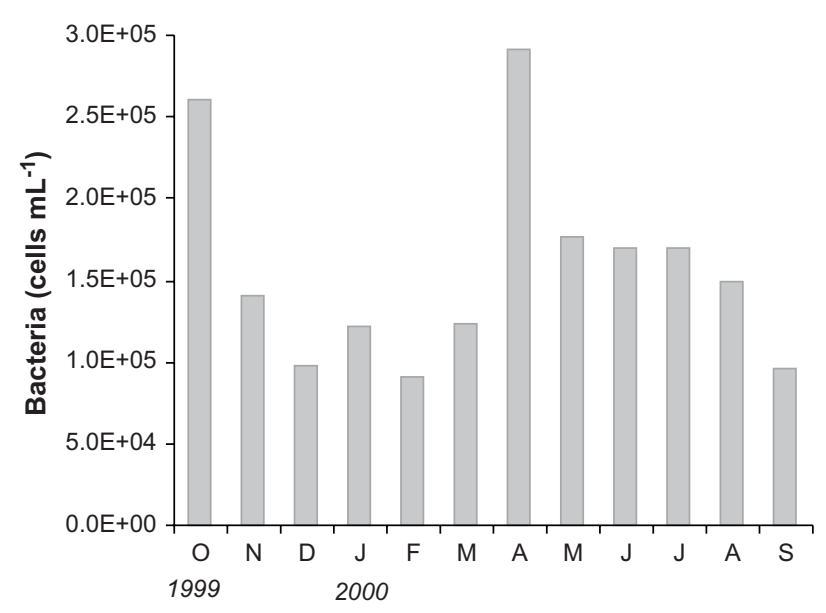

Fig. 5. Temporal variations in bacterial abundance in Niel Bay.

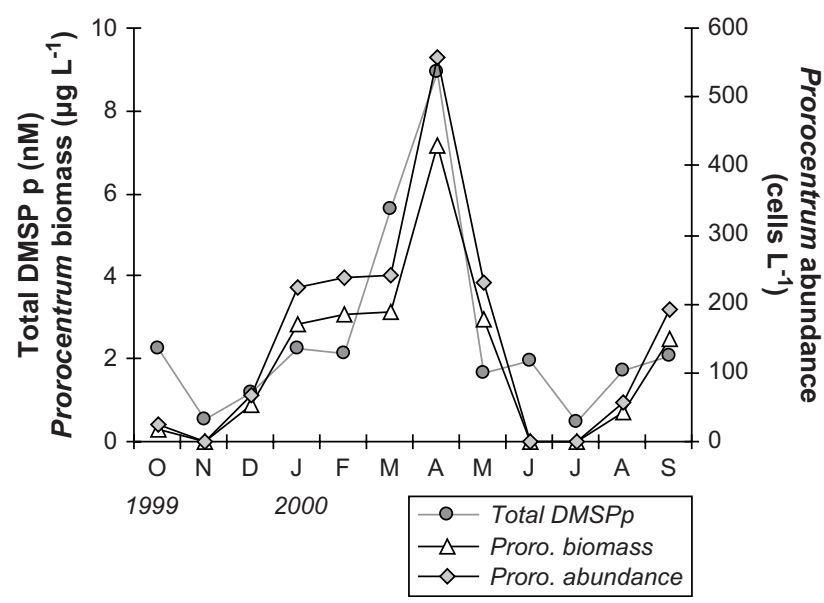

Fig. 6. Relationships between total $\mathrm{DMSP}_{p}$ and $P$. compressum abundance and biomass in Niel Bay.

\subsubsection{Intracellular DMSP concentrations}

Intracellular DMSP concentrations were obtained for a particulate size class, by dividing DMSP values by the biomass contained in the size class, with biomass expressed as protein content.

3.3.6.1. $>90 \mu \mathrm{m}$ fraction. Intracellular $\mathrm{DMSP}_{>} 90$ concentrations

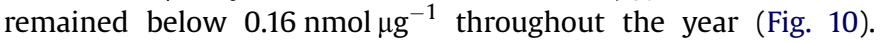
Intracellular $\mathrm{DMSP}_{>90}$ was generally higher than intracellular DMSP $_{0.2-5}$, but lower than that calculated for the 5-90 $\mu \mathrm{m}$ fraction. The $>90 \mu \mathrm{m}$ size class seemed to produce more DMSP in January

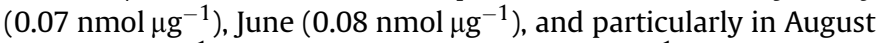

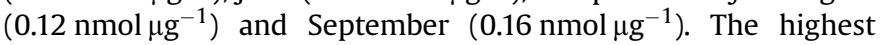
values recorded, in August-September coincided with high zooplankton abundances (Fig. 2).

3.3.6.2. 5-90 $\mu \mathrm{m}$ fraction. Intracellular $\mathrm{DMSP}_{5-90}$ concentrations fluctuated strongly over time, with a large increase to

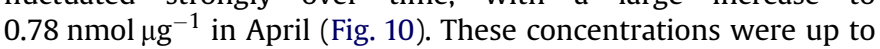
50 times higher than those calculated for the other fractions, suggesting particularly active DMSP $_{5-90}$ production. The highest intracellular $\mathrm{DMSP}_{5-90}$ concentrations coincided precisely with the peak abundance of Prorocentrum compressum (Spearman's rank correlation test: $r=0.549 ; p=0.064)$. We compared temporal variations in intracellular $\mathrm{DMSP}_{5-90}$ with temporal variations in

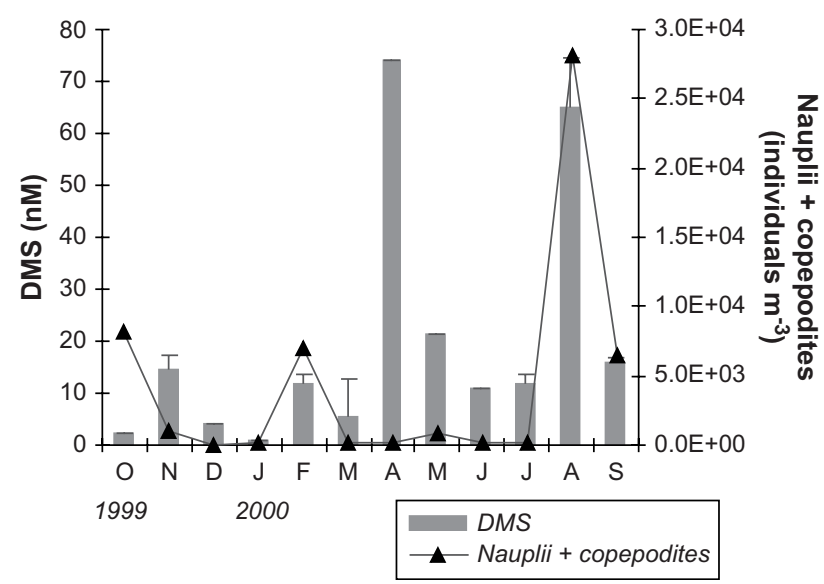

Fig. 7. Relationships between DMS concentrations and abundance of nauplii and copepodites in the zooplankton of Niel Bay. 


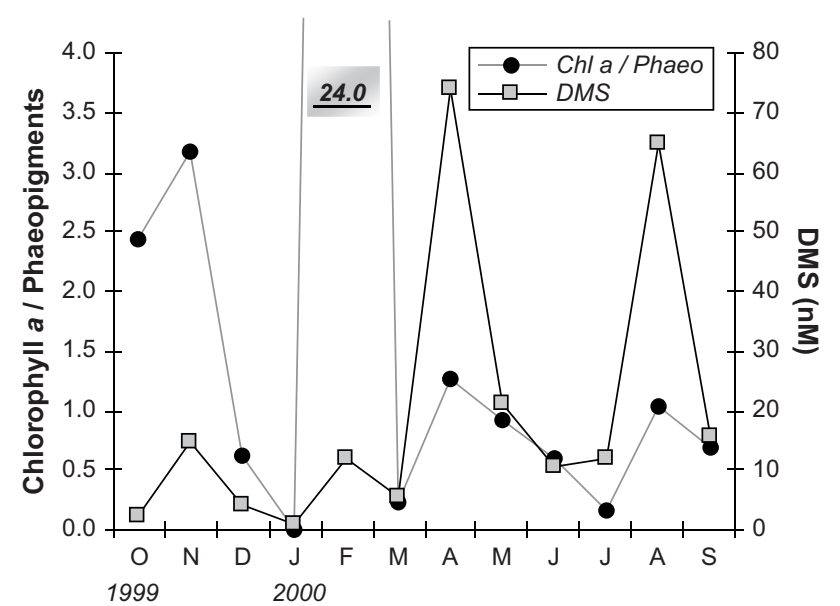

Fig. 8. Relationships between DMS concentrations and chlorophyll $a$ to pheopigment ratio in Niel Bay.

nitrate concentration. For most of the year (from October to May), these two concentrations varied in opposite manners: during the nitrate enrichment of seawater, from October to January, intracellular DMSP $_{5-90}$ levels remained low, rapidly increasing from February to April when nitrate was exhausted. This pattern was confirmed in May, when a secondary nitrate peak coincided with a decrease in intracellular DMSP ${ }_{5-90}$. These observations suggest a possible negative relationship between intracellular DMSP and nitrate concentrations in seawater.

3.3.6.3. $0.2-5 \mu \mathrm{m}$ fraction. The $0.2-5 \mu \mathrm{m}$ size class produced the smallest amounts of DMSP, with low intracellular DMSP levels, not

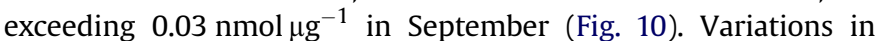
intracellular $\mathrm{DMSP}_{0.2-5}$ concentrations were characterized only by moderate increases between December and March, and then in July and September.

\section{Discussion}

According to Ignatiades (2005), there is no clear international consensus concerning the appropriate factors to be used to determine the trophic status of seawater. Using chlorophyll

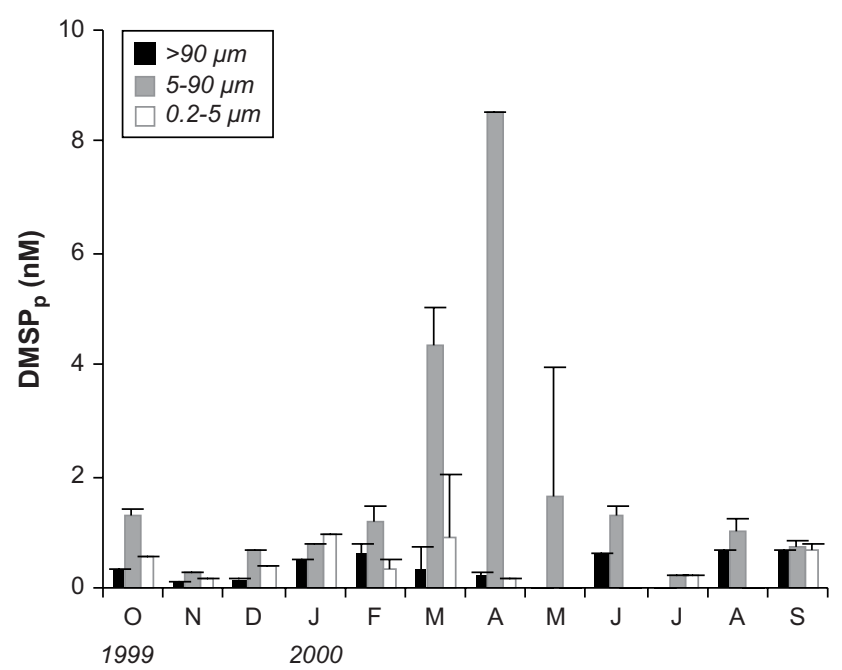

Fig. 9. Temporal variations of DMSP concentrations in the $>90,5-90$ and $0.2-5 \mu \mathrm{m}$ fractions in Niel Bay.

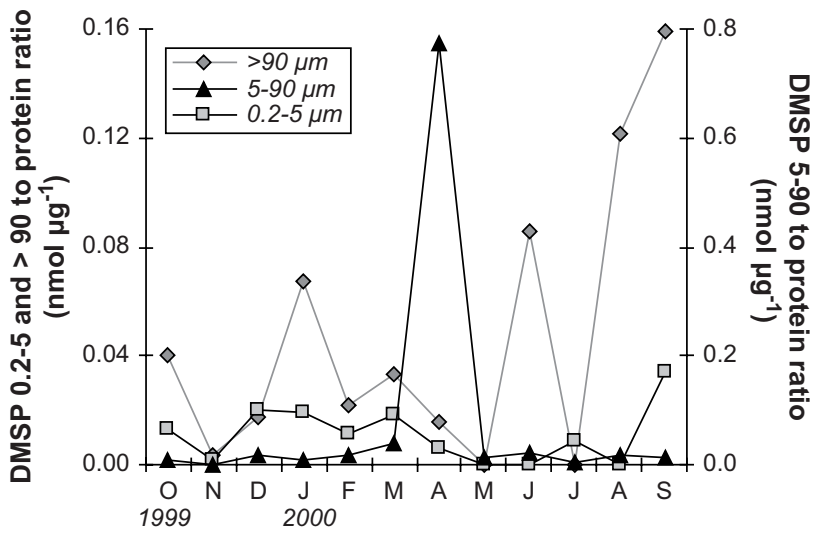

Fig. 10. Temporal variations of DMSP to protein ratio for the $>90,5-90$ and $0.2-5 \mu \mathrm{m}$ fractions in Niel Bay.

a concentration as a reliable indicator of water quality in the Aegean Sea (Eastern Mediterranean), Ignatiades estimated that oligotrophy was reached at chlorophyll $a$ concentrations below $0.5 \mu \mathrm{g} \mathrm{L}^{-1}$, whereas concentrations between 0.5 and $1.0 \mu \mathrm{g} \mathrm{L}^{-1}$, and $>1.0 \mu \mathrm{g} \mathrm{L}^{-1}$ indicated mesotrophy and eutrophy, respectively. In Niel Bay, the annual mean concentration of chlorophyll $a$ was $0.4 \mu \mathrm{g} \mathrm{L}^{-1}$, confirming the classification of Niel Bay as a Mediterranean oligotrophic study sites, as reported by Jamet et al. (2005).

The annual mean total DMSP $_{p}$ concentration in Niel Bay was $2.6 \mathrm{nM}(0.5-8.9 \mathrm{nM})$. This average is much lower than the total DMSP $_{p}$ levels recorded in the Little Bay of Toulon where a mean annual value of $16.1 \mathrm{nM}(2.1-58.8 \mathrm{nM})$ was obtained. This finding probably results from differences in trophic levels, Niel Bay being an oligotrophic study site whereas Little Bay of Toulon displays eutrophication, with much higher nutrient concentrations and phytoplankton biomasses and abundances (Jean et al., 2006). Similarly, total DMSP $p$ levels in Niel Bay were much lower than those in other coastal systems of the Mediterranean Sea (Barcelona harbor: 3.4-4.7 $\mu \mathrm{M}$ ) (Belviso et al., 2000), in the Gulf of Maine ( $>200 \mathrm{nM}$ ) (Matrai and Keller, 1993; Townsend and Keller, 1996) or in the Gulf of St Lawrence (6-117 nM) (Cantin et al., 1996). As previously stated, it was difficult to compare our results with previous studies as few studies have been carried out on oligotrophic coastal systems. However, Ledyard and Dacey (1996) reported DMSP concentrations similar to those obtained in our study (2-9 nM) in the oligotrophic Sargasso Sea.

In Niel Bay, total $\mathrm{DMSP}_{p}$ concentrations followed a strongly seasonal pattern, peaking in spring (March-April) at values 18 times higher than the autumnal minima. According to Liss et al. (1993), DMSP concentrations follow a strong seasonal pattern in temperate coastal waters. In most studies, DMSP levels are highest in spring, consistent with our results (Christaki et al., 1996; Kwint and Kramer, 1996; Townsend and Keller, 1996; Dacey et al., 1998; Van Duyl et al., 1998). Our lowest DMSP $p$ concentrations were recorded in autumn, during the heavy rains affecting the Toulon area. Indeed, the subsequent drop in salinity of Niel Bay waters generated hypo-osmotic conditions that may have induced phytoplankton cell lysis, resulting in the release of large amounts of intracellular DMSP into seawater. The same phenomenon, based on the properties of DMSP as an osmolyte, has also been observed by Dickson and Kirst (1986) in cultures of Tetraselmis subcordiformis. In Niel Bay waters, a role for DMSP as an osmolyte was suggested by the peak in total DMSP $p$ levels observed in March, coinciding with an increase in salinity.

In Niel Bay, particles of $0.2-5 \mu \mathrm{m}$, consisting of bacteria and picoplankton cells (which were not counted), contributed only $20 \%$ 
of the total DMSP $p$ pool. Other authors also considered the contributions of smaller particle fractions to be negligible: Meyerdierks et al. (1997) for particles $<5 \mu \mathrm{m}$ in the southern Atlantic Ocean, and Corn et al. (1996) for the picoplankton fraction, which accounted for only $10 \%$ of total DMSP $p$ in the Ligurian Sea. By contrast, particles in the size range $5-90 \mu \mathrm{m}$ accounted for a mean of $62 \%$ of the total DMSP $_{p}$. This contribution increased at the same time as total $\operatorname{DMSP}_{p}$, indicating the key role played by the $5-90 \mu \mathrm{m}$ fraction in Niel Bay DMSP production. In Barcelona harbor, Belviso et al. (2000) found that $\mathrm{DMSP}_{p}$ in the $>10 \mu \mathrm{m}$ size fraction accounted for more than $90 \%$ of the total $\mathrm{DMSP}_{p}$, consistent with our results. Microzooplankton organisms, such as ciliates and tintinids, may also be present (Belviso et al., 2000) in Niel Bay, but the DMSP-productive $5-90 \mu \mathrm{m}$ fraction consisted principally of phytoplankton cells. In this ecosystem, most of the phytoplankton species counted were dinoflagellates or diatoms. However, dinoflagellates clearly dominated the phytoplankton community, with an annual mean biomass of $68 \%$, versus only $32 \%$ for diatoms. The dinoflagellate population increased in the spring, in May, whereas several smaller diatom peaks were observed, in December, February-March, May and August. In December and May, peaks in the diatom population coincided precisely with high nitrate levels in seawater.

As previously reported, no correlation was found between the total $\operatorname{DMSP}_{p}$ and biomass expressed as chlorophyll $a$ or total protein concentrations (Jean et al., 2006). Similarly, DMSP ${ }_{5-90}$ was not correlated with chlorophyll $a$ or protein concentrations in the 5-90 $\mu \mathrm{m}$ fraction. This absence of correlation has been observed in many oceanic areas (Kwint and Kramer, 1996; Townsend and Keller, 1996; Belviso et al., 2000). Some authors agree that there is not necessarily a positive relation between chlorophyll $a$ concentration and phytoplankton biomass, chlorophyll $a$ being a better marker of photosynthetic activity (Bienfang and Szyper, 1981). To strengthen possible relationships between DMSP levels and the plankton communities of Niel Bay, we calculated specific phytoplankton biomasses, using the biovolumes determined by microscopy. However, DMSP concentrations were always not correlated with total phytoplankton biomass. According to Simo et al. (1997), such correlations occur only during monospecific blooms of phytoplankton producing DMSP. DMSP production is generally limited to particular groups of phytoplankton, such as dinoflagellates and prymnesiophytes (with coccolithophorids), whereas diatoms are thought to produce smaller amounts of DMSP (Belviso et al., 1990; Liss et al., 1993). We obtained similar results in a previous study using phytoplankton isolates, which showed DMSP contents to be five times higher in dinoflagellates (125 mM) than in diatoms (25 mM) (Jean et al., 2005).

However, in Niel Bay, where dinoflagellates dominated the phytoplankton community in terms of biomass and abundance, DMSP $_{p}$ and DMSP $_{5-90}$ were not correlated with this taxonomic group. Jean et al. (2005) demonstrated large differences in DMSP production among the various dinoflagellates isolated, with DMSP contents ranging from $37 \mathrm{mM}$ in Ceratium furca to $3400 \mathrm{mM}$ in Alexandrium minutum. In Niel Bay, dinoflagellates were more diverse, although some species, such as Prorocentrum compressum and Gymnodinium sp., were more abundant than others. The relatively high level of dinoflagellate diversity observed in this ecosystem may weaken the positive relationship generally found with DMSP. Indeed, when we investigated relationships with individual dinoflagellate species, some significant positive correlations were observed between total $\mathrm{DMSP}_{p}$ and $P$. compressum abundance or biomass (Spearman's rank correlation test: $r=0.704 ; p=0.011$ ), and between DMSP $_{5-90}$ and $P$. compressum abundance or biomass (Spearman's rank correlation test: $r=0.648 ; p=0.023$ ), that were not revealed in the study by Jean et al. (2006). In the Mediterranean Bay of Villefranche-sur-mer,
Belviso et al. (1990) also found that DMSP was predominantly associated with the population of Prorocentrum sp. This suggests that $P$. compressum may play an important role in the DMSP production of Niel Bay, similar to that of A. minutum in Little Bay of Toulon. The non-negligible intracellular DMSP contents previously measured in Prorocentrum arcuatum (442 mM) support this hypothesis (Jean et al., 2005). However, the DMSP contents found in Prorocentrum were (8 times) lower than those in Alexandrium, potentially accounting for the much lower (by a factor of 7) maximal DMSP levels in Niel Bay than in Toulon Bay. These differences were also amplified by differences in phytoplankton abundances and biomasses between the two study sites. The $>90 \mu \mathrm{m}$ particulate fraction contributed $18 \%$ annually to the total $\operatorname{DMSP}_{p}$ pool. The highest $\mathrm{DMSP}_{>90}$ concentrations occurred when zooplankton abundances were maximal, in February and August. Thus, DMSP may accumulate in zooplankton, but it does so to a lesser extent than in phytoplankton. The chlorophyll $a$ peak associated with moderate developments of dinoflagellate and diatom populations during this period suggests that the DMSP in the zooplankton in Niel Bay probably came from phytoplankton cells ingested during grazing. Some authors have reported that the DMSP ingested by zooplankton is not metabolized (Kwint et al., 1996a; Tang, 2000). Taking this result into account, zooplankton organisms may be partly responsible for the bioaccumulation of DMSP in the trophic chain.

DMS concentrations in Niel Bay were found to be higher than those of its precursor, DMSP. The DMS to DMSP $p$ ratio, which was high other than in October and January (below 1 ), had a mean value of 11.4. This situation is unusual in oligotrophic areas, in which most authors report a low DMS to DMSP $p$ ratio, as exemplified by Belviso et al. (2004), who reported a ratio close to 0, and Dacey et al. (1998), who obtained a maximal ratio of 1.6 and a mean ratio of 0.57 during summer in the oligotrophic Sargasso Sea. Kiene and Slezak (2006) have demonstrated that pressure and the handling of large volumes of seawater influence the extraction of $\mathrm{DMSP}_{p}$ as dissolved DMSP $\left(\mathrm{DMSP}_{d}\right)$, and consequently the release of DMS. As we suspected that the method used during the filtration procedure might account for our high DMS to DMSP $p$ ratio, we used a corrective factor $(37.3 \% \pm 7.9 \%)$ to take into account the potential losses of $\mathrm{DMSP}_{p}$ and gains of DMS resulting from filtration artifacts. After the application of this corrective factor to DMS and $\mathrm{DMSP}_{p}$ concentrations, we again obtained a high DMS to DMSP $p$ ratio, of between 4.3 (applying the maximal corrective factor $45.2 \%$ ) and 6.2 (applying the minimal corrective factor $29.4 \%$ ), demonstrating that our results were not due to filtration artifacts. Without taking the filtration artifacts into account, we compared the ratio obtained at Niel Bay with that obtained in the Little Bay of Toulon. The annual mean DMS to DMSP $p$ ratio in Niel Bay (11.4) was about three times higher than that obtained in the Little Bay of Toulon (4.2). However, DMS and DMSP $p$ concentrations were three times and six times higher, respectively, in Little Bay than in Niel Bay (Jean et al., 2006). All these observations suggest that DMS levels in Niel Bay could have a source other than pelagic plankton, which are clearly less abundant in Niel Bay than in Little Bay. As benthic macroalgae, such as Ulva lactuca, Polysiphonia fastigiata and Polysiphonia lanosa, are able to produce DMSP (Challenger, 1951; Cantoni and Anderson, 1956; Greene, 1962), it is possible that $\mathrm{DMSP}_{d}$ and DMS production by benthic macroalgae or by macrophytes, such as Posidonia spp., might account for high levels of DMS production by non-planktonic species. Few studies have considered the contribution of benthic macroalgae and/or macrophytes to DMS and DMSP concentrations, as most oceanographic studies generally take place in deep waters, in which the activity of these organisms is negligible relative to that of the pelagic plankton. However, as our study site in Niel Bay is shallow (depth $5 \mathrm{~m}$ ), the seawater column is sufficiently clear for 
high levels of photosynthetic activity at the benthic level and, thus, for high levels of DMSP and DMS production by benthic macroalgae and/or macrophytes. However, Nedwell et al. (1994) observed in the North Sea that concentrations of the precursor, DMSP, were higher in the surface sediments than in the seawater column, suggesting that, in the shallow waters of Niel Bay, high DMS concentrations may also result from the conversion of DMSP accumulated in sediments.

It has been suggested that DMS production may be indirectly increased by the sloppy feeding of zooplankton grazing on algal cells (Dacey and Wakeham, 1986; Belviso et al., 1990; Wolfe et al., 1994). Similarly, significant correlations have sometimes been observed between zooplankton biomass and DMS concentrations, confirming that zooplankton grazing on phytoplankton contributes to DMS production (Leck et al., 1990; Yang et al., 2000). In Niel Bay, we observed no such correlations, but the DMS peaks observed in February and in August coincided with higher zooplankton abundances. Simo and Pedros-Alio (1999) reported the existence of a "summer DMS paradox" in oligotrophic marine ecosystems. In these environments, high DMS levels may occur in summer, at precisely the times at which phytoplankton abundances are low. These authors suggested that this paradox may result from the poor degradation of DMS by some bacteria, the activity of which is decreased by nutrient limitation and strong UVB radiation. This may be the case in August in Niel Bay, with summer DMS concentrations in this ecosystem not exclusively dependent on zooplankton activity.

Similarly, zooplankton did not seem to be involved in the maximal DMS concentrations recorded in April, as suggested by the low abundance of zooplankton during this period. According to Kwint et al. (1996b), DMS release is particularly active during phytoplankton growth and during phytoplankton senescence. In April, total $\mathrm{DMSP}_{p}$ concentrations were maximal, at the same time as Prorocentrum compressum and bacterial abundances peaked. Consequently, in April, high DMS concentrations are probably associated principally with growth of the dinoflagellate population, as this taxonomic group may contain the DMSP-lyase enzyme converting DMSP into DMS (Ishida, 1968; Niki et al., 2000). These DMS levels may also result from natural DMSP excretion by dinoflagellates, followed, as suggested by the higher bacterial abundances in spring, by conversion of the extracellular DMSP into DMS mediated by bacterial DMSP-lyase. The chlorophyll $a$ to pheopigment ratio was used by Shenoy et al. (2006) as an indicator of the health of phytoplankton cells. In our study, the positive relationship that seems to exist between this ratio and DMS concentrations suggests that, in Niel Bay, DMS production was associated with phytoplankton growth. This seems to be the case in April in particular, when peak DMS concentrations coincided with a peak in the chlorophyll $a$ to pheopigment ratio. This relationship even indicates that the high DMS concentrations measured in February and in August were probably due to zooplankton grazing on healthy phytoplankton cells.

Finally, our study suggests that intracellular DMSP concentrations in Niel Bay may be negatively related to the concentration of nitrate in seawater, with DMSP contents rapidly increasing when nitrate levels are low. Such a relationship has been observed in many marine ecosystems (Andreae and Barnard, 1984; Andreae et al., 1985; Curran et al., 1998; Yang, 2000). DMSP is structurally similar to glycine betaine (GBT), a well known osmolyte in phytoplankton. However, unlike GBT, DMSP does not contain nitrogen (Kwint, 1997). DMSP synthesis includes a transamination step which would encourage algae to synthesize DMSP rather than GBT in nitrogen-deficient conditions (Gage et al., 1997). According to Stefels (2000), nitrogen is released during DMSP production from methionine, allowing intracellular nitrogen regeneration and conferring resistance to nitrogen deficiency. This relationship may also account for the largest amounts of DMSP being produced by nitrophilic phytoplankton species, such as Phaeocystis sp. or Alexandrium minutum, blooming in eutrophicated ecosystems.

\section{Conclusions}

As previously observed in the eutrophicated Little Bay of Toulon, our data suggest that particulate DMSP in the oligotrophic Niel Bay originated principally from phytoplankton. The greatest producer of DMSP in the Niel Bay phytoplankton community seemed to be the dinoflagellate species Prorocentrum compressum, whereas Alexandrium minutum was the principal DMSP producer at Little Bay of Toulon. The lower intracellular DMSP contents in Prorocentrum than in the nitrophilic $A$. minutum, amplified by differences in phytoplankton abundances and biomasses between the two study sites, may account for the lower DMSP concentrations recorded in Niel Bay (oligotrophic) than in Little Bay of Toulon (eutrophicated). During the study, some of the total particulate DMSP pool was also stored in the zooplankton compartment, particularly in copepods (nauplii and copepodites), as a result of their grazing on phytoplankton. The high DMS levels recorded in Niel Bay do not seem to result purely from pelagic plankton, but instead may also be generated through the activity of benthic macroalgae or macrophytes, such as Posidonia spp., meadows of which are present in this ecosystem. The shallow configuration of Niel Bay, by increasing the photosynthetic activity of these macrophytes and favoring the resuspension of the DMSP accumulated in sediments, may also increase DMS levels.

\section{Acknowledgments}

The authors thank the Institut Universitaire Technologique of the Université du Sud Toulon - Var and the Département Génie Biologique for the technical support during the experimental work.

\section{References}

Andreae, M.O., Barnard, W.R., 1984. The marine chemistry of dimethylsulfide Marine Chemistry 14, 267-279.

Andreae, M.O., Ferek, R.J., Bermond, F., Byrd, K.P., Engstrom, R.T., Hardin, S Houmere, P.D., Lemarrec, F., Ramdonck, H., 1985. Dimethylsulfide in the marine atmosphere. Journal of Geophysical Research 90, 891-900.

Belviso, S., Kim, S.K., Rassoulzadegan, F., Krajka, B., Nguyen, B.C., Mihalopoulos, N., Buat-Menard, P., 1990. Production of DMSP and DMS by a microbial food web. Limnology and Oceanography 35, 1810-1821.

Belviso, S., Christaki, U., Vidussi, F., Marty, J.C., Vila, M., Delgado, M., 2000. Die variations of the DMSP-to-chlorophyll a ratio in Northwestern Mediterranean surface waters. Journal of Marine Systems 25, 119-128.

Belviso, S., Moulin, C., Bopp, L., Stefels, J., 2004. Assessment of a global climatology of oceanic dimethylsulfide (DMS) concentrations based on SeaWiFS imagery (1998-2001. Canadian Journal of Fisheries and Aquatic Sciences 61, 804-816.

Bienfang, P.K., Szyper, J.P., 1981. Phytoplankton dynamics in the subtropical Pacific Ocean of Hawaii. Deep-Sea Research 28, 981-1000.

Cantin, G., Levasseur, M., Gosselin, M., Michaud, S., 1996. Role of zooplankton in the mesoscale distribution of surface dimethylsulfide concentrations in the Gulf of St Lawrence, Canada. Marine Ecology Progress Series 141, 103-117.

Cantoni, G.L., Anderson, D.G., 1956. Enzymatic cleavage of dimethylpropiothetin by Polysiphonia lanosa. Journal of Biological Chemistry 222, 171-177.

Challenger, F., 1951. Biological methylation. Advances in Enzymology 12, 429-491.

Charlson, R.J., Lovelock, J.E., Andreae, M.O., Warren, S.G., 1987. Oceanic phytoplankton, atmospheric sulfur, cloud albedo and climate. Nature 326, 655-661.

Christaki, U., Belviso, S., Dolan, J.R., Corn, M., 1996. Assessment of the role of copepods and ciliates in the release to solution of particulate DMSP. Marine Ecology Progress Series 141, 119-127.

Corn, M., Belviso, S., Partensky, F., Simon, N., Christaki, U., 1996. Origin and importance of picoplanktonic DMSP. In: InKiene, R.P., Visscher, P.T., Keller, M.D. Kirst, G.O. (Eds.), Biological and Environmental Chemistry of DMSP and Related Sulfonium Compounds. Plenum Press, New York, pp. 191-201.

Curran, M.A.J., Jones, G.B., Burton, H., 1998. Spatial distribution of dimethylsulfide and dimethylsulfoniopropionate in the Australasian sector of the Southern Ocean. Journal of Geophysical Research 103, 16677-16689. 
Dacey, J.W.H., Wakeham, S.G., 1986. Oceanic dimethylsulfide: production during zooplankton grazing on phytoplankton. Science 233, 1314-1316

Dacey, J.W.H., Blough, N.V., 1987. Hydroxide decomposition of DMSP to form DMS. Geophysical Research Letters 14, 1246-1249.

Dacey, J.W.H., Howse, F.A., Michaels, A.F., Wakeham, S.G., 1998. Temporal variability of dimethylsulfide and dimethylsulfoniopropionate in the Sargasso Sea. Deep Sea Research I 45, 2085-2104.

Despiau, S., Gourdeau, J., Jamet, D., Geneys, C., Jamet, J.L., 2002. Seawater DMS in a perturbed coastal ecosystem. Hydrobiologia 489, 107-115.

Dickson, D.M.J., Kirst, G.O., 1986. The role of ß-dimethylsulfoniopropionate, glycine, betaine and homarine in the osmoacclimation of Platymonas subcordiformis. Planta 167, 536-543.

Duarte, C.M., Agusti, S., Kennedy, H., Vaque, D., 1999. The Mediterranean climate as a template for Mediterranean marine ecosystems: the example of the northeast Spanish littoral. Progress in Oceanography 44, 245-270.

Gage, D.A., Rhodes, D., Nolte, K.D., Hicks, W.A., Leustek, T., Cooper, A.J.L. Hanson, A.D., 1997. A new route for synthesis of dimethylsulphoniopropionate in marine algae. Nature 387, 891-894.

Gondwe, M., Krol, M., Gieskes, W., Klaassen, W., de Baar, H., 2003. The contribution of ocean-leaving DMS to the global atmospheric burdens of DMS, MSA, $\mathrm{SO}_{2}$, and $\mathrm{NSS} \mathrm{SO}_{4}$. Global Biogeochemical Cycles 17 (2), 1056

Greene, R.C., 1962. Biosynthesis of dimethyl-ß-propiothetin. Journal of Biological Chemistry 237, 2251-2254.

Howard, E.C., Henriksen, J.R., Buchan, A., Reisch, C.R., Burgmann, H., Welsh, R. Ye, W., Gonzalez, J.M., Mace, K., Joye, S.B., Kiene, R.P., Whitman, W.B. Moran, M.A., 2006. Bacterial taxa that limit sulfur flux from the ocean. Science $314,649-652$.

Ignatiades, L., 2005. Scaling the trophic status of the Aegean Sea, eastern Mediterranean. Journal of Sea Research 54, 51-57.

Ishida, Y., 1968. Physiological studies on the evolution of dimethylsulfide. Kyoto University, Memoirs of the College of Agriculture 94, 47-82.

Jamet, J.L., Boge, G., Richard, S., Geneys, C., Jamet, D., 2001. The zooplankton community in bays of Toulon area (northwest Mediterranean Sea, France). Hydrobiologia 457, 155-165.

Jamet, J.L., Jean, N., Boge, G., Richard, C., Jamet, D., 2005. Plankton succession and assemblage structure in two neighbouring littoral ecosystems in the NorthWest Mediterranean Sea. Marine and Freshwater Research 56, 69-83.

Jean, N., 2002. Etude du DMSP et du DMS dans deux écosystèmes littoraux marins de niveaux trophiques différents (Méditerranée Occidentale, France): relations avec les facteurs abiotiques et biotiques. PhD thesis, Univ. Sud Toulon-Var, France, 283 pp.

Jean, N., Boge, G., Jamet, J.L., Richard, S., Jamet, D., 2005. Annual contribution of different plankton size classes to particulate dimethylsulfoniopropionate in a marine perturbed ecosystem. Journal of Marine System 53, 235-247.

Jean, N., Boge, G., Jamet, J.L., Jamet, D., 2006. Comparison of ß-dimethylsulfoniopropionate (DMSP) levels in two mediterranean ecosystems with different trophic levels. Marine Chemistry 101, 190-202.

Kettle, A.J. Andreae, M.O., Amouroux, D., Andreae, T.W., Bates, T.S., Berreisheim, H., Bingemer, H., Boniforti, R., Curran, M.A.J., Di Tullio, G.R., Helas, G., Jones, G.B. Keller, M.D., Kiene, R.P., Leck, C., Levasseur, M., Malin, G., Maspero, M., Matrai, P., Mc Taggart, A.R., Mihalopoulos, N., NGuyen, B.C., Novo, A., Putaud, J.P. Rapsomanikas, S., Roberts, G., Schebeske, G., Sharma, S., Simo, R., Staubes, R. Turner, S., Uher, G., 1999. A global database of sea surface dimethylsulfide (DMS measurements and a procedure to predict sea surface DMS as a function of latitude, longitude, and month. Global Biogeochemical Cycles 13, 399-444.

Kettle, A.J., Andreae, M.O., 2000. Flux of dimethylsulfide from the oceans: a comparison of updated data sets and flux models. Journal of Geophysical Research 105, 26793-26808.

Kiene, R.P., Service, S.K., 1991. Decomposition of dissolved DMSP and DMS in estuarine waters: dependence on temperature and substrate concentration. Marine Ecology Progress Series 76, 1-11.

Kiene, R.P., Linn, L.J., Gonzalez, J., Moran, M.A., Bruton, J.A., 1999. Dimethylsulfoniopropionate and methanethiol are important precursors of methionine and protein-sulfur in marine bacterioplankton. Applied Environmental Microbiology $65,4549-4558$

Kiene, R.P., Linn, LJ., Bruton, J.A., 2000. New and important roles for DMSP in marine microbial communities. Journal of Sea Research 43, 209-224.

Kiene, R.P., Slezak, D., 2006. Low dissolved DMSP concentrations in seawater revealed by small-volume gravity filtration and dialysis sampling. Limnology and Oceanography: Methods 4, 80-95.

Kirst, G.O., Thiel, C., Wolff, H., Nothnagel, J., Wanzek, M., Ulmke, R., 1991. Dimethylsulfoniopropionate (DMSP) in ice algae and its possible biological role. Marine Chemistry 35, 381-388.

Kwint, R.L.J., Kramer, K.J.M., 1996. Annual cycle of the production and fate of DMS and DMSP in a marine coastal system. Marine Ecology Progress Series 134, 217-224.

Kwint, R.L.J. Irigoien, X., Kramer, K.J.M., 1996a. Copepods and DMSP. In: Kiene, R.P. Visscher, P.T., Keller, M.D., Kirst, G.O. (Eds.), Biological and Environmenta Chemistry of DMSP and Related Sulfonium Compounds. Plenum Press, New York, pp. 239-252.

Kwint, R.L.J., Quist, P., Hansen, T.A., Dijkhuizen, L., Kramer, K.J.M., 1996b. Turnover of dimethylsulfoniopropionate and dimethylsulfide in the marine environment: a mesocosm experiment. Marine Ecology Progress Series 145, 223-232.

Kwint, R.L.J. 1997. The origin of DMS(P)cies: a survey of the sources and sinks of the two dimethylated sulphur compounds ß-dimethylsulphoniopropionate (DMSP) and dimethylsulfide (DMS), $141 \mathrm{pp}$.
Leck, C., Larsson, U., Bagander, L.E., Johansson, S., Hajdu, S., 1990. Dimethylsulfide in the Baltic sea: annual variability in relation to biological activity. Journal of Geophysical Research 95, 3353-3363.

Ledyard, K.M., Dacey, J.H.W., 1996. Microbial cycling of DMSP and DMS in coastal and oligotrophic seawater. Limnology and Oceanography 41, 33-40.

Legendre, L., Watt, W.D., 1971-1972. On a rapid technique for plankton enumeration. Paris, Annales de l'Institut Océanographique 58, 173-177.

Le Poupon, C., 1994. Automatisation d'un procédé d'analyse de l'azote organique dissous après minéralisation en conditions réductrices. $\mathrm{PhD}$ thesis, Univ. Sud Toulon-Var, France, 182 pp.

Liss, P.S., Malin, G., Turner, S.M., 1993. Production of DMS by marine phytoplankton. In: Restelli, G., Angeletti, G. (Eds.), Dimethylsulfide: Oceans, Atmosphere and Climate. Kluwer Academic Publishing, Dordrecht, The Netherlands, pp. 1-14.

Lohman, H., 1908. Untersuchungen zur Feststellung des vollstandigen Gehaltes des Meeres an Plankton. Wiss. Meeresunters 10, 132-170.

Lorenzen, C.J., 1967. Determination of chlorophyll and pheopigments: spectrophotometric equations. Limnology and Oceanography 12, 343-346.

Lovelock, J.E., Maggs, R.J., Rasmussen, R.A., 1972. Atmospheric dimethylsulfide and the natural sulfur cycle. Nature 237, 452-453.

Lowry, O.H., Rosebrough, N.J., Farr, A.L., Randall, R.J., 1951. Protein measurement with the Folin phenol reagent. Journal of Biological Chemistry 193, 265-275.

Malin, G., Wilson, W.H., Bratbak, G., Liss, P.S., Mann, N.H., 1998. Elevated production of dimethylsulfide resulting from viral infection of cultures of Phaeocystis pouchetii. Limnology and Oceanography 43, 1389-1393.

Matrai, P.A., Keller, M.D., 1993. Dimethylsulphide in a large-scale coccolithophore bloom in the Gulf of Maine. Continental Shelf Research 13, 831-843.

Meyerdierks, D., Bolt, B., Kirst, G.O., 1997. Spatial and vertical distribution of particulate dimethylsulfoniopropionate (DMSP) during spring in the Atlantic sector of the Southern Ocean. Deep-Sea Research 44, 283-297.

Michaud, S., Levasseur, M., Cantin, G., 2007. Seasonal variations in dimethylsulfoniopropionate and dimethylsulfide concentrations in relation to the plankton community in the St Lawrence Estuary. Estuarine, Coastal and Shelf Science 71, 741-750.

Murphy, J., Riley, J.P., 1962. A modified single solution method for the determination of phosphate in natural waters. Analytica Chimica Acta 27, 31-36.

Nedwell, D.B., Shabbeer, M.T., Harrison, R.M., 1994. Dimethylsulfide in North Sea waters and sediments. Estuarine, Coastal and Shelf Science 39, 209-217.

Niki, T., Kunugi, M., Otsuki, A., 2000. DMSP-lyase activity in five marine phytoplankton species: its potential importance in DMS production. Marine Biology 136, 759-764.

Paillard, M., Gravez, V., Clabaut, P., Walker, P., Blanc, J.J., Boudouresque, C.F., Belsher T., Urscheler, F., Poydenot, F., Sinnassamy, J.M., Augris, C., Peyronnet, J.P., Kessler, M., Augustin, J.M., Le Drezen, E., Prudhomme, C., Raillard, J., Pergent, G., Hoareau, A., Charbonnel, E., 1993. Cartographie de l'herbier de Posidonie et des fonds marins environnants de Toulon à Hyères (Var - France). Reconnaissance par sonar latéral et photographie aérienne. Notice de présentation. IFREMER \& GIS POSIDONIE, pp. 1-36.

Porter, K.J., Feig, Y.S., 1980. The use of DAPI for identifying and counting aquatic microflora. Limnology and Oceanography 25, 943-948.

Shenoy, D.M., Paul, J.T., Gauns, M., Ramaiah, N., Kumar, M.D., 2006. Spatial variations of DMS, DMSP and phytoplankton in the Bay of Bengal during the summer monsoon 2001. Marine Environmental Research 62, 83-97.

Simo, R., Grimalt, J.O., Albaiges, J., 1993. Field sampling and analysis of volatile reduced sulphur compounds in air, water and wet sediments by cryogenic trapping and gas chromatography. Journal of Chromatography A $655,301-307$

Simo, R., Grimalt, J.O., Albaiges, J., 1997. Dissolved DMS, DMSP and DMSO in western mediterranean waters. Deep-Sea Research II 44, 929-950.

Simo, R., 1998. Trace chromatographic analysis of dimethylsulfoxide and related methylated sulfur compounds in natural waters. Journal of Chromatography A 807, 151-164.

Simo, R., Pedros-Alio, C., 1999. Role of vertical mixing in controlling the oceanic production of dimethylsulfide. Nature 402, 396-399.

Stefels, J., Van Boekel, W.H.M., 1993. Production of DMS from dissolved DMSP in axenic cultures of the marine phytoplankton species Phaeocystis sp. Marine Ecology Progress Series 97, 11-18.

Stefels, J., Dijkhuizen, L., Gieskes, W.W.C., 1995. DMSP-lyase activity in a spring phytoplankton bloom off the Dutch coast, related to Phaeocystis abundance. Marine Ecology Progress Series 123, 235-243.

Stefels, J., 2000. Physiological aspects of the production and conversion of DMSP in marine algae and higher plants. Journal of Sea Research 43, 183-197.

Steinke, M., Malin, G., Gibb, S.W., Burkill, P.H., 2002. Vertical and temporal variability of DMSP-lyase activity in a coccolithophorid bloom in the northern North Sea. Deep Sea Research II 49, 3001-3016.

Sunda, W., Kieber, D.J., Keine, R.P., Huntzman, S., 2002. An antioxidant function for DMSP in marine algae Nature 418, 317-320.

Tang, K.W., 2000. Dynamics of dimethylsulfoniopropionate (DMSP) in a migratory grazer: a laboratory simulation study. Journal of Experimental Marine Biology and Ecology 243, 283-293.

Todd, J.D., Rogers, R., Li, Y.G., Wexler, M., Bond, P.L., Sun, L., Curson, A.R.J., Malin, G., Steinke, M., Johnston, A.W.B., 2007. Structural and regulatory genes required to make the gas dimethyl sulfide in bacteria. Science 315, 666-669.

Townsend, D.W., Keller, M.D., 1996. Dimethylsulfide and dimethylsulfoniopropionate in relation to phytoplankton in the Gulf of Maine. Marine Ecology Progress Series 137, 229-241. 
Turner, S.M., Malin, G., Liss, P.S., Harbour, D.S., Holligan, P.M., 1988. The seasonal variations of DMS and DMSP concentrations in nearshore waters. Limnology and Oceanography 33, 364-375.

Utermöhl, H., 1958. Zur Vervollkommung der quantitativen Phytoplankton-Methodik. Mitt. intern. Verein. Theor. und Angew. Limnol 9, pp. 1-38.

Van Duyl, F., Gieskes, W.W.C., Kop, A.J., Lewis, W.E., 1998. Biological control of shortterm variations in the concentration of DMSP and DMS during a Phaeocystis spring bloom. Journal of Sea Research 40, 221-231.

Van Rijssel, M., Buma, A.N.G., 2002. UVR induced stress does not affect DMSP synthesis in the marine prymnesiophyte Emiliana huxleyi. Aquatic Microbial Ecology 28, 167-174.
White, R.H., 1982. Analysis of dimethylsulfonium compounds in marine algae. Journal of Marine Research 40, 529-536.

Wolfe, G.V., Sherr, E.B., Sherr, B.F., 1994. Release and consumption of DMSP from Emiliana huxleyi during grazing by Oxyrrhis marina. Marine Ecology Progress Series 111, 111-119.

Wood, E.D., Armstrong, A.A.J., Richards, F.A.,1967. Determination of nitrate in sea wate by cadmium - copper reduction to nitrite. Journal of Marine Biology 47, 23-31.

Yang, G.P., 2000. Spatial distribution of dimethylsulfide in the South China Sea. Deep-Sea Research I 47, 177-192.

Yang, G.P., Zhang, J.W., Li, L., Qi, J.L., 2000. Dimethylsulfide in the surface water of the East China Sea. Continental Shelf Research 20, 69-82. 